\title{
Om Subovs Ruslandshistorie for det 20. århundrede
}

\author{
Mette Skak* \\ Institut for Statskundskab, Aarhus Universitet, Danmark
}

\begin{abstract}
On the historiography of Zubov et al.'s History of Russia in the 20th Century Around 2009, a certain Kremlin-sanctioned Vergangenheitsbewältigung of Russia's Soviet past developed. A case in point is the collective two-volume work edited by Andrei B. Zubov, Istoriya Rossii. XX vek, published in 2009. Societal agency is said to be stressed over structural forces, but it is mainly the agency of Lenin, Stalin and later Soviet leaders that is analyzed. The narrative of the times before Stalin's ascent to power emphasizes repression, terror and planned famine as precursors of the totalitarian excesses under Stalin (19231953). The originality of Zubov's historiography is evident in his approach to the Great Fatherland War of 1941-1945, which Zubov refers to as The Soviet-Nazi War. Further, the narrative of the Cold War era culminates in an 'imperial overstretch' theory about the Soviet collapse. However, Zubov has been vehemently criticized for lack of critical rigor; his work represents an awkward mix of liberal enlightenment and obscurantism in its veneration of the fascistoid thinker Ilyin. Today Russia officially operates with one historical truth about the years 1941-45 and is hereby distancing itself from scholars like Zubov.
\end{abstract}

Keywords: Russia, historiography, Soviet history, Vergangenheitsbewältigung

Historien er en af den russiske præsident Vladimir Putins foretrukne slagmarker. For nylig belærte han omverdenen om optakten til Anden Verdenskrig og søgte blandt andet at gøre polakkerne til de egentlige nazi-kollaboratører (Putin, 2020; Poulsen, 2020; Deutsche Welle, 2019). De russiske historikere Aleksej Miller (2020) og Igor Torbakov (2011) taler ligefrem om mindekrige mellem Europa og Rusland. Ligesom flertallet af russere glorificerer Putin ofte Stalin som indbegrebet af den sovjetiske krigsindsats under Anden Verdenskrig og bagatelliserer hans terror og folkedrab (Bækken \& Enstad, 2020). Ligeledes skelner tv-værten Dmitrij Kiseljov mellem "den store Stalin« - dvs. verdenskrigens hærfører - og den totalitære hverdags »lille Stalin $~^{1}{ }^{1}$ Nogle vestlige historikere peger imidlertid på, at mens Dmitrij Medvedev

\footnotetext{
${ }^{1}$ Jeg skylder Torben Heuer tak for at have gjort mig opmærksom herpå. Sagen omtales af Kolesnikov (2019).

^Kontaktinformasjon: Mette Skak, e-post: msk@ps.au.dk 
var Ruslands præsident (2008-2012) pågik der under overfladen det, som tyskerne kalder for Vergangenheitsbewältigung - at man bemestrer fædrelandets traumatiske fortid ved åbent at bearbejde de menneskefjendske sider af dets historie (Enstad, 2011, s. 338f; Sherlock, 2011, 2016, s. 49-50; Kolstø, 2019; Skak, 2009). Derfor er det værd at undersøge, om der findes russisk historieskrivning, der grundlæggende udfordrer den fremherskende autoritære statsdyrkelse i Rusland med det såkaldte Filippov-lærebogssystem som klimaks. ${ }^{2}$

Et oplagt eksempel er tobindsværket Istorija Rossii. XX vek (Bind 1, s. 18941939, bind 2, s. 1939-2007), der udkom i 2009 som et kollektivt værk skrevet af hele 45 mestendels russiske fagfolk med historieprofessoren Andrej Borisovitj Subov som hovedredaktør, herefter blot Subov (2009). Trods det beskedne oplag vakte udgivelsen opsigt, og det russisksprogede Wikipedia (2020) henviser til mange anmeldelser og debat. I 2011 fulgte et genoptryk, og i 2017 blev værket relanceret af et andet forlag som et handy trebindsværk (Subov, 2017). Forfatterholdet rummer mange forskellige fagligheder og kæpheste såsom kirkehistorie for de gejstliges vedkommende, selv om det ikke oplyses hvem, der har skrevet hvad. Derfor er det ikke nogen let gennemskuelig, homogen og stringent fremstilling. Det, der fascinerer, er fortælleglæden og viljen til at se fortiden i øjnene på godt og ondt. Subov (2009) er tillige udgivet på tjekkisk, og måske bliver trebindsversionen Subov (2017) udgivet på engelsk.

Subov personificerer den russiske liberale fløjs vilje til Vergangenheitsbewältigung og blev internationalt kendt for sin kritik af annekteringen af Krim-halvøen, der førte til hans afskedigelse fra det russiske diplomatiske akademi MGIMO (Yaffa, 2014; Albats \& Tsukanova, 2013). Det gør det interessant at se nærmere på hans og medforfatternes historieskrivning i sammenhæng med de historiepolitiske konjunkturer i Kreml. Det er formålet med dette analytiske essay, der følgelig prioriterer enkeltværket på bekostning af helheden af historiebøger (herom se Miller, 2010). Derved kan jeg tillige bidrage til formidlingen af Ruslands samtidshistorie så at sige på landets egne præmisser. For ligesom den danske historiker Ulrik Langen (2020) og velsagtens flere andre tillægger jeg det særlig værdi at formidle andre landes historie via

\footnotetext{
${ }^{2}$ Filippov-lærebogssystemet består af lærervejledningen Filippov (2007), to lærebøger i Ruslands historie - 1945-2007 (Danilov, Utkin \& Filippov, 2007) og 1900-1945 (Danilov \& Filippov, 2012) samt en metodebog om 1900-1945 (Danilov, 2008), og er meget omdiskuteret. Med et oplag på samlet 250.000 eksemplarer, hvor andre lærebøgers oplag højst er 15.000, opnåede Filippov \& Co. ifølge Miller (2010, s. 19-21) at dominere historieundervisningen i Rusland. Værket forkaster totalitarisme-teorien om det sovjetiske diktatur som en ren koldkrigstilgang, hvad Miller (2010) afviser. Som alternativ fremelskes næsegrus loyalitet over for fortidens og nutidens statslige magthavere, idet deres vold mod befolkningen bagatelliseres. Sherlock (2016, s. 49) bemærker, at Filippov \& Co. giver Vesten skylden for Stalins overgreb og herved genopliver den sovjetiske historieskrivning, mens David Brandenberger (2009) ser systemet som en ny Kratkij kurs (1938). Miller (2010) fremhæver den manipulation, der ligger i, at Putin-tidens propagandabegreb »det suveræne demokrati« er rammen for forståelsen af nutidens Rusland.
} 
deres egne markante historikere. Det konkrete valg af Subov (2009) kan derudover begrundes i tre argumenter, der fremføres af en anden markant historiker, nemlig den respekterede veteran inden for studiet af Ruslands historie Richard Pipes (2009). For det første afviser Subov og hans hold den gængse offerfortælling om Rusland og omverdenen og vedgår blandt andet åbent Katyn-massakren på Polens elite i 1940. For det andet anvendes international historieforskning - faktisk figurerer Pipes på listen over værkets forfattere! - den slags var tabu i Stalintiden. For det tredje anlægges ikke kun statens og magthavernes perspektiv som i Filippovsystemet, idet Subov-værket inddrager det bredere samfund, folks frygt og håb. Pipes (2009) hylder af disse grunde Subov (2009) som et håb om en ny og afbalanceret russisk selvforståelse.

Af omslaget på værket fremgår det, at den strukturhistorie, som marxismen kendes for, her fravælges til fordel for en historieskrivning med mennesket i centrum, inklusive hvad Subov-holdet anser for nødvendige moralske refleksioner. Grundet værkets omfang på næsten 2000 informationsspækkede sider har mit formidlende essay form af en række punktnedslag i kronologisk orden for ikke at sprænge alle rammer. Først vil jeg løbende præsentere, hvad jeg anser for værkets styrker med afsæt i følgende periodisering af Ruslands historie op gennem det 20. århundrede, som strukturerer værkets trebindsudgave (Subov, 2017):

- 1894-1922: "Hvordan Rusland kom ind i det 20. århundrede»

- 1923-1953: "Stalinismens epoke»

- 1953-2008: „Nedbrydningen af den totalitære stat og bevægelsen mod et nyt Rusland"

Denne kronologiske gennemgang bygger på Subov (2009), hvad sidetalsreferencer angår, og har som metode at drage paralleller til anden relevant historiefaglig litteratur. Derpå drøftes, hvordan værket blev modtaget inklusive den heftige kritik fra historiefagligt hold. Sluttelig rejses spørgsmålet, om Subov-værket er en enlig svale i lyset af førnævnte Kreml-sanktionerede Vergangenheitsbewältigung ud fra, hvad vi nu ved.

\section{4-1922: "Hvordan Rusland kom ind i det 20. århundrede»}

Denne Ruslandshistorie skrives ud fra en normativ kristen position, og Subov (bind 1, s. 5) taler ligefrem om sandheden i ental om forehavendet. Det vil nogen kalde naivt og utilbørligt, men omvendt anså den svenske nobelpristager Gunnar Myrdal eksplicitte værdipræmisser for vejen til videnskabelighed. Det er forfriskende, at værkets identifikation med Rusland og det russiske folk ikke ender i romantik om den ædle russiske folkesjæl. Tværtimod er dets argument om historien op til det 20. århundrede, at det var fravceret af solidaritet mand og mand og kvinde imellem i det russiske samfund, der giorde Rusland sårbart for de radikale bolsjevikkers erobring af magten i 1917 (bind 1, s. 7 ff.; s. 206; s. 289). Brødtekstens første sætning lyder: "I det 
20. århundrede skete en katastrofe $i$ vort land. I 1917-1954 blev mangfoldige millioner af Ruslands bedste borgere myrdet af russerne selv, andre millioner blev fordrevet" (bind 1, s. 7). Ergo en historieskrivning, der vægter den folkelige agens - handlekraft - og ikke kun dæmoniserer Lenin, Stalin og andre bolsjevikkiske nøgleaktører. Dette budskab om medansvar er indlysende vigtigt i enhver Vergangenheitsbewältigung.

Hvad Lenin og Stalin angår, er der unægtelig tale om dæmonisering, men iblandet analytiske betragtninger. Lenin skildres som hemmelig tysk indflydelsesagent, idet hans syn på Første Verdenskrig var, at det var ligegyldigt, om hans hjemland tabte krigen; det gjaldt om at gøre krigen til en borgerkrig (bind 1, s. 127). Lenin anså verdenskrige for ønskelige som potentielle "revolutionære situationer". Dette kernepunkt i marxismen-leninismen var også karakteristisk for Stalin, viser Subov (bind 1, s. 916). Ligeledes gør værket med rette Lenins lære om partiets hegemoni eller med andre ord partidiktaturet til indbegrebet af leninisme (Jowitt, 1992). For modsat nazismen gjorde leninismen partiet til historiens handlende og ufejlbarlige "subjekt". Ligesom vestlige historikere gør Subov opløsningen af den grundlovgivende forsamling i januar 1918 til Lenins essentielle statskup og begyndelsen på Den Russiske Borgerkrig (Kulavig, 2010). Dog benævnes tiden fra oktober 1917 til oktober 1922 "Krigen om Rusland «. Beskrivelsen af borgerkrigen balancerer mellem umiskendelig sympati for de hvide anti-bolsjevikker og tilpas nøgterne pointer om fx kosakkernes og sibirjakkernes lokale loyaliteter og heraf følgende flygtige støtte til den landsdækkende hvide sag og pogromer, faneflugt og kaotiske evakueringer fra Krim i 1920.

Særligt velgørende er Subovs opgør med en af den sovjetiske historieskrivnings trosartikler, som det hedder hos den amerikanske historiker Peter Kenez (2006, s. 36) - myten om, at sovjetmagten lige fra begyndelsen var truet på livet af den såkaldte allierede intervention, dvs. Storbritanniens, Frankrigs og USA's væbnede indgriben på de hvides side. Den blev ukritisk overtaget af den internationale venstrefløj som en bekvem forklaring på, at Lenins regime greb til vold og undertrykkelse kaldet rød terror. Subov gør det klart, at stærke kræfter i Storbritannien saboterede Churchills ønske om at hjælpe de hvide; franskmændene var lunkne, for ikke at tale om USA (bind 1, s. 630, s. 653, s. 672 f.). Det fremgår, at kun det indædt antibolsjevikkiske Japan for alvor hjalp den hvide krigsførelse i kampene omkring Bajkal-søen (bind 1, s. 701). Subov omtaler Den Fjernøstlige Republik, som Lenin oprettede som værn mod truslen fra Japan, og som blev nedlagt, da de 70.000 japanske tropper som de sidste fremmede styrker drog hjem i efteråret 1922. Vestmagterne derimod drog hurtigt hjem.

Tendensen til at dæmonisere Lenin skyldes navnlig mordet på zarfamilien samt den brutale forfølgelse af kirken og de troende. Ateismen var vitterlig noget af det, der gjorde bolsjevikkerne forhadte i det russiske folkedyb. Her vil jeg nævne, at den danske historiker, Lenin-biograf og tidligere partiorganiserede kommunist Kurt Jacobsen (2012, s. 275 ff.) understreger, at Lenins blodtørst over for kirken kulminerede i tiden efter sejren i borgerkrigen. Ifølge ham var der indiskutabelt sygelige 
træk i Lenins fremfærd. Lige så velgørende er det, når Subov lægger vægt på Lenins nedbrydning af de institutioner og de elementer af en retsstat, som zarismen indebar. Lenin var pioner i opbygningen af et statsligt undertrykkelsesapparat dels ved at oprette det første sovjetiske hemmelige politi, Tjeka, i december 1917, dels ved at åbne for brugen af koncentrationslejre som forspil til GULag-forvaltningens uendelige øhav af arbejdslejre.

Lenins røde terror i årene 1918-1922 belyses blandt andet med en liste over 23 velkendte massakrer på befolkningen med i alt 482.500 dødsofre (bind 1, s. 550-551). Terroren tolkes som et anslag mod solidariteten og den medmenneskelige anstændighed - ikke ulig når den anerkendte franske historiker Nicolas Werth (2003, s. 97) gør terroren til en kopernikansk vending i grusomhed. Den sovjetiske historieskrivning var derimod absurd forløjet, når den hyldede Tjeka-chefen Dzjerzjinskij som "revolutionens frygtløse ridder" (Syrov, 1979, s. 227 ff.). Subov henfører denne mytologi til Stalintiden og gør Dzjerzjinskij til ophav til den særlige sovjetiske kontraspionagekultur, hvor de statslige sikkerhedsorganer manisk ledte efter "udenlandske sammensværgelser og spionage" (bind 1, s. 817f.). Subov og hans medforfattere nærer heller ikke høje tanker om hverken Trotskij eller Bukharin, men anser det for et logisk træk, da Lenin i 1922 kørte Stalin i stilling som sin efterfølger ved at oprette posten som generalsekretær for partiet til ham. Her er værket på linje med nyere Stalin-forskning som fx Stephen Kotkin (2014).

\section{3-1953: „Stalinismens epoke»}

Beskrivelsen af denne periode udgør en nok så vigtig Vergangenheitsbewältigung. Subov gennemgår årene 1923-28 under overskriften "Den Falske Termidor" som karakteristik af Lenins omsving til den mere moderate NEP-politik fra 1921 (bind 1, s. 766-855). Det falske ligger ifølge Subov i dels den aggressive forfølgelse af kirken, dels det taktiske overlæg bag NEP. En kendsgerning er det jo, at den tvangskollektivisering, der fulgte fra 1929 og frem med dens landbrugsstruktur af kollektivbrug, blev til sovjetisk normalitet, ikke NEP. Nobelpristageren Aleksandr Solsjenitsyn stod oprindelig bag Subov-værket, ${ }^{3}$ og man mærker hans indflydelse på den indignerede beskrivelse af "nedkæmpelsen af bondestanden", som det hedder (bind 1, s. 868 ff.). Ligesom Solsjenitsyn kalder Subov den nye tilstand for "det andet livegenskab» (bind 1, 883). Anerkendte vestlige historikere bruger lige så stærke gloser: "folkedrab ", "terrorøkonomi«, eller "apokalypse" (Naimark, 2010; Service, 2005, s. 264 ff.; Kotkin 2017, s. 70). Subov viser, hvordan NEP gled over i en genopblussen af borgerkrigen, fordi man igen konfiskerede korn som forspil til tvangskollektiviseringen. Subov bruger det russiske ord golodomor (sultedød) både om den politisk fremkaldte hungersnød

\footnotetext{
${ }^{3}$ Siden sprang han fra grundet uenighed (Solsjenitsyn, 2008; Wikipedia, 2020). Hvori den bestod, forbliver lidt uklart, da det næppe var fremstillingens kristne grundsyn, der var anstødsstenen for ham. Mere herom senere.
} 
i Ukraine (Holodomor på ukrainsk) og den sultkatastrofe, der ramte de tilsvarende frugtbare regioner i Rusland.

I pagt med værkets vægtning af mennesket i historien indgår mange biografier, herunder et Stalin-portræt, der gør op med al Stalin-romantik. Det kan diskuteres, hvor lødig evidensen og analysen af Stalin er, men som korrektiv til fortidens og nutidens insisteren på de statslige magthaveres kløgt og pålidelighed er stoffet velgørende. Fagfolk som Alter Litvin og John Keep (2005: 96) ville givetvis bifalde følgende: "Stalin berer personligt ansvaret for, at hans kvart århundrede lange regeringstid blev den allermest dystre og blodige $i$ hele Ruslands historie" (bind 1, s. 864). Subov underbygger dommen med, at Stalin gjorde vilkårlige arrestationer - dvs. justitsmord - til krumtap i planopfyldelsen i form af kvoter, som »efterforskerne" (rasnarjadniki) gik frem efter (sammesteds). Endvidere: "Stalin berer ansvaret for samfundets moralske forfald, idet man tvang folk til at bryde med sleegtninge og til offentligt at kreve folk, som alle vidste var uskyldige, henrettet "(sammesteds). Stalin-forståelsen og Subovs syn på hele Sovjetepoken hviler på begrebet totalitarisme, der af mange historikere og politologer anses for mere retvisende for den type ideologiske diktaturer end alternativerne (bind 1, s. 859). ${ }^{4}$

Hvad angår den udbredte vildfarelse om, at Stalin lagde verdensrevolutionen på hylden midt i 1920'erne, gengiver Subov Stalins prøvestensdoktrin af 1927. Det var et trylleslag, der tvang alverdens partiorganiserede kommunister ud i næsegrus loyalitet over for Sovjetunionen som stat og Stalin som forvalter af partilinjen (bind 1, s. 944 f.). Heri har man nøglen til Stalins magt både ude og hjemme, idet organisationen Komintern jo hvervede professionelle sovjetiske spioner som danskeren Georg Laursen Moltke (Riisbro, 2015, 2016). Subov-holdets sagkundskab er mærkbar, når de forklarer, hvordan planøkonomien fungerede; herunder at Stalin botaniserede i Marx' ideer om skattepolitik (bind 1, s. 915f.). Den håbløst politiserede kadrepolitik tilsidesatte meritokratiet til fordel for de ideologisk nævenyttige, men ofte brutale og inkompetente vydvysjentsy (dvs. "dem, der blev forfremmet"; bind 1, s. 917 ff.). Man kunne tro, at Subov bringer en røverhistorie til torvs om dengang i 1930, da Stalin greb til falskmøntneri for at skaffe hård valuta ved at trykke ca. 1 million falske 100-dollarsedler (bind 1, s. 953). Men skandalen er blevet analyseret i et lødigt fagtidsskrift for slavistik (Krammer, 1971). En anden positiv overraskelse er den balancerede analyse af Den Spanske Borgerkrig, som Sovjetunionen greb militært ind i.

Ellers vægtes talmaterialet om Stalins massakre på den sovjetiske elite kendt som Den Store Terror (1936-1938). Den afgrundsdybe angst for natlig arrestation, der

\footnotetext{
${ }^{4}$ Subovs inspiration er klassikerne Friedrich og Brzezinski (1956), men også Pipes kendes som fortaler for totalitarisme-tesen samt politologen Juan Linz (2000). Historikerne Litvin og Keep (2005, s. 97) fremhæver den russiske historiker Nikita Lomagin. Subov selv har krydset klinger med en anden markant russisk historiker, Aleksandr Tjubarjan, om totalitarisme, hvor Tjubarjan fremhæver den alternative moderniseringstilgang, der betoner Sovjet-epokens fremskridt, i tillæg til de totalitære træk, hvis essens var GULag-lejrene (Albats \& Tsukanova, 2013).
} 
ramte alle, betones, og Anna Akhmatovas digt Rekviem citeres (bind 1, s. 967). Et kildemæssigt scoop er syersken Anna Pavlovas harmdirrende klageskrivelse til Stalin, hvor Subov dokumenterer, at henrettelsesbølgen ramte mange andre end samfundets spidser (bind 1, s. 959-962). Beretningen om 1930'ernes rædsler konkluderer: "Vort folk blev et folk af stikkere og forredere over for dets ncermeste. Det solidariske fallesskabs princip blev tyndslidt og forsvandt " (bind 1, s. 1006). Kun blandt de russiske emigranter i Europa, Kina og USA blomstrede samfundslivet. De ulykkelige, der levede under Stalins hæl omtales med det finurlige udtryk podsovjetskie ljudi - undersovjetiske mennesker (bind 1, s. 1009). Subov gennemgår de internationale dramaer op gennem 1930'erne, Kominterns omsving til de tilsyneladende pragmatiske "folkefronter« samt Sovjetunionens afsindige oprustning og offensive militære doktrin (bind 1, s. 994 ff.) Her flugter Subov med vigtige værker om det, jeg vil kalde for den sovjetiske hypermilitarisme (Samuelson, 2000; Stone, 2000; Heikka, 2000; Musial, 2008; Poulsen, 2008, s. 61 ff.). Dog halter kildevalget om året 1939; herom senere.

Det mest kontroversielle ved bind 2 af Subov (2009) er værkets betegnelse for den afgørende sovjetiske del af Anden Verdenskrig. I stedet for den gængse sovjetiske og moderne russiske term for forsvarskrigen fra 1941 til 1945, nemlig Den store Fædrelandskrig, skrives denne del af Ruslands historie i det 20. århundrede under overskriften "Den Sovjetisk-Nazistiske Krig». Ifølge Subov (2010) godtog Solsjenitsyn sprogbrugen, der understreger, at Hitlers felttog mod øst med alt, hvad det indebar af racisme og grusomheder, bragte alle sovjetkritiske sovjetborgere i et frygteligt dilemma. For selv om flertallet endte med at gå helhjertet ind i krigsførelsen mod de nazistiske angribere, var der kollaboration (Poulsen, 2008, s. 182 ff.). Subov anslår, at 1,24 millioner sovjetborgere kæmpede på tysk side, heraf 400.000 russere og 250.000 ukrainere (bind 2, s. 112). Værket udfordrer både den sovjetiske og den gængse nye russiske historieskrivning ved at omtale den sovjetkritiske kollaboratør general Vlasov og hans styrker med empati og forbinde ham med idealerne fra Februarrevolutionen i 1917 samt opstandene mod sovjetmagten i Tambov og Kronstadt i 1921 (bind 2, s. 155). Vlasov gjorde det godt under forsvaret af Moskva, men blev taget til fange i 1942 og fik så en "hær« på 50.000 mand. Subov er på det rene med det håbløse i Vlasovs forsøg på at omgøre krigen til et væbnet oprør mod Stalin. På tysk side nød han kun støtte fra folk som von Stauffenberg, der stod bag det mislykkede Hitler-attentat i 1944 .

Verdenskrigsanalysen er uhyre stofrig, afbalanceret og kompetent, så vidt jeg kan skønne. Den har brod mod Stalin, men understreger, at Hitler forregnede sig fatalt ved at undervurdere den slagkraft, Stalin kunne mobilisere. Omvendt anså Stalin Hitler for klog nok til ikke at angribe. Stalin bebrejdes, at han evakuerede materiel, ikke mennesker, og hans krigsførelse var et blodbad for Den Røde Hær. Et sted standser teksten op og beder læseren om at se nærmere på krigstidens fotos: „Alt efter årstiden bærer soldaterne baret eller øreklaphue. Men hvor mange har hjelme?« spørges der retorisk (bind 2, s. 184). Folk blev sat til at angribe maskingeværreder og rydde minefelter; parerede soldaten ikke ordre, endte han i en straffebataljon. Tre 
måneders straffebataljon svarede til 10 års indespærring i GULag (sammesteds). Det hemmelige politi fik med Stalins ordre nr. 227 fra 1941 lov til at meje "panikmagere og kujoner" ned ved fronten (bind 2, s. 126). Gennem erindringer og anekdoter ønsker Subov at give læseren empati for krigens virkelige helte blandt dem, der kæmpede for Stalin. Eksempelvis Marija Oktjabrskaja, der for sine opsparede 50.000 rubler købte en kampvogn, som hun kaldte "min krigsveninde", og som hun kæmpede mod tyskerne sammen med, indtil hun blev dødeligt såret i 1944 (bind 2, s. 140 f.). Hvad angår Subovs bidrag til en Vergangenheitsbewältigung, bringes vidnesbyrd om de utallige krigsvoldtægter mod tyske civile kvinder, som fordømmes som ukristelig hævn (bind 2, s. 161-166). Sænkningen af det tyske flygtningeskib Wilhelm Gustloff anskues som en sovjetisk udåd, mens massakren på Kievs jøder i Babyj Jar beskrives som indbegrebet af en nazistisk udåd, som den sovjetiske historieskrivning imidlertid tav om.

Lige så prisværdigt er det, at Subov-holdets fremstilling ikke forklejner den verdenskrig, som USA og Storbritannien udkæmpede, selv om de ikke brugte deres soldater som kanonføde. Den allierede Lend and Lease-hjælp til den sovjetiske krigsførelse skabte taknemmelighed over for vestmagterne og bestod i hundredtusindvis af lastbiler, jeeps, drejebænke, lokomotiver osv. samt 15 millioner par soldaterstøvler (bind 2, s. 70). Spørgsmålet om åbningen af den anden front, der skulle aflaste Den Røde Hær, drøftes nøgternt, hvorimod de allierede kritiseres for at udlevere sovjetborgere og eksilrussere i tysk fangenskab til Stalins forgodtbefindende, da krigen sluttede. De sovjetiske krigsfangers skæbne gøres til en forbrydelse i klasse med Holodomor og Holocaust; en ugerning, der skyldtes, at Sovjetunionen stod uden for Genèvekonventionerne (bind 2, s. 103). Ganske dristigt gøres der op med den glorificerende sovjetiske historieskrivning om partisankrigen mod nazisterne. Den udarterede til marodøruvæsen mod andre civile og tillægges ingen militær betydning (bind 2, s. 95f.). Stalins Vinterkrig mod Finland i 1939-40 beskrives som en sovjetisk angrebskrig; generelt hersker der indlevelse i Finlands situation, Baltikum og Polen mv.

Subov gør regnestykket for den ufatteligt blodige sovjetiske del af Anden Verdenskrig op ved at opgøre "uerstattelige tab«, dvs. tab i menneskeliv blandt mænd i den værnepligtige alder og den øvrige befolkning. I alt omkom 17 millioner fortrinsvis unge mænd fordelt på:

\begin{tabular}{ll}
\hline Unge mænd, der omkom i tysk fangenskab & 3,3 millioner \\
Mænd, der omkom i sovjetiske arbejdslejre & 0,9 millioner \\
Dræbte i kamp i antisovjetiske delinger & 0,3 millioner \\
Mænd, der blev henrettet af Den Røde Hær & 0,1 millioner \\
Unge mænd dræbt i kamp for Den Røde Hær & 12,4 millioner \\
\hline
\end{tabular}

Subov skriver, at tabene i den sidste kategori er omstridte (bind 2, s. 184). De officielle tal for Den Røde Hærs tab ligger på det halve, mens udenlandske kilder når tæt 
på tallet 13 millioner omtrent som i Subovs opgørelse. Alle er enige om, at de tyske tab på østfronten - der bestemt ikke var nogen flødeskumsfront! - lå langt under dette. Kun halvdelen af de sovjetborgere, der blev sendt i krig, vendte hjem. Dette mandefald fik langvarige demografiske følger, idet der i 1959 var halvanden gang så mange kvinder som mænd i alderen 30 til 74 år. Subov (bind 2, s. 185) anslår det samlede tab i civile menneskeliv til 10 millioner - mest kvinder, børn og gamle:

\begin{tabular}{ll}
\hline Omkomne under blokaden af Leningrad & 1,0 millioner \\
Jøder, der blev dræbt af nazisternes terror & $>0,5$ millioner \\
Dræbte af nazisterne i partisanernes bagland & 0,5 millioner \\
Omkomne under deportation som "upålideligt folk" & ca. 0,3 millioner \\
Børn, der døde grundet den højere børnedødelighed & 1,3 millioner \\
Døde som følge af de stærkt forringede levevilkår & 6,4 millioner \\
\hline
\end{tabular}

Krigens enorme materielle omkostninger fremgår af, at byerne Rsjev, Voronesj, Belgorod, Orjol, Sevastopol, Kharkov og Stalingrad måtte opføres helt fra bunden. Den bredere samfundsdynamik kommer til udtryk i en vigtig betragtning om opblødningen af afstanden mellem magthaverne og folket - altså krigens relative frisættelse af sovjetborgeren (bind 2, s. 186). En jødisk sovjetisk videnskabsmand har fortalt, at han trygt åbnede døren, da det hemmelige politi bankede ham op en nat under krigen. Men før krigen og lige efter ville han være blevet skræmt fra vid og sans (Bonwetsch, 2000, s. 138; Stites, 2000). Stalins forlig med kirken i 1943 og krigen ud anskues som en sigende indrømmelse.

Men værket går til angreb på tesen om, at sejren kun var mulig takket være det sovjetiske samfundssystem gennem følgende fem modargumenter (bind 2, s. 186 f.): For det første var krigen næppe kommet uden netop dette samfundssystem. ${ }^{5}$ For det andet ville man have stået langt bedre rustet uden den sovjetiske planøkonomi. For det tredje var den sovjetiske mobiliseringsøkonomi utilstrækkelig, idet sejren var betinget af den enorme økonomiske hjælp til nøglesektorer fra de allierede. For det fjerde var den terror, der hjalp Sovjetunionen til sejr, også den, der i krigens første år forårsagede fremmedgørelse. Ergo var den afgørende årsag til sejren Hitlers umenneskelige politik som det, der svejsede folk sammen til forsvar af fædrelandet. For det femte "må man ikke glemme, at de vigtigste vardier udgøres af livet, friheden og menneskets vardighed. Folket opretter staten for at tage vare på vardierne og ikke for, at staten selv på meningsløs vis skal brede sig ud over verdenskortet». Denne etisk uangribelige

\footnotetext{
${ }^{5}$ Til det modargument vil jeg sige, at nok var Hitler og nazisterne indædte antibolsjevikker, idet de kaldte alliancen mellem dem og det fascistiske Italien, det militaristiske Japan samt den tyskbesatte verden såsom Danmark for anti-Kominternpagten. Men vestlig forskning viser, at den ideologiske krumtap var en blanding af jødehad, almen racisme og en alvorligt ment økonomisk imperialisme jfr. Lebensraum-doktrinen (Thies, 2012).
} 
betragtning hentyder til den brutale sovjetisering af meget af omverdenen. Men den er analytisk naiv, hvorfor kritikken slog ned her (Samuelson, 2010); mere herom senere.

Om slutfasen af Stalin-tiden fremhæves den fornyede totalitære undertrykkelse og ensretning i form af den såkaldte Sjdanovsjina og Leningrad-affæren, og Subov opholder sig ved sulten i 1947. Som led i beretningen om den kolde krig genoptrykkes hele Churchills "jerntæppetale«. Også vinklingen af denne del af Stalinhistorien er bemærkelsesværdig, idet overskriften er "Rusland og Stalins forberedelse til Den (ikke indtrufne) Tredje Verdenskrig «. Men den følger op på Subovs konklusion om 1920'erne og især 1930'erne - at Stalin tænkte i offensive baner - og som sagt anså Lenin og Stalin verdenskrige for revolutionære situationer, der skulle udnyttes geopolitisk. Subov giver imidlertid Stalin-fortolkningen den drejning, at han under indtryk af den storpolitiske prestige, han høstede hos de allierede under Anden Verdenskrig, forlod den ideologiske messianisme og anlagde en mere almindelig stormagtsimperialisme. Men målsætningerne smeltede snarere sammen (Zubok, 2009, s. 9).

Hvad angår Stalins offensive fremfærd eller revisionisme, fortjener Subov honnør for at benytte den samme rumænske hovedkilde til vor viden, som den nyeste vestlige forskning i Stalins gådefulde 1951-initiativ gør (bind 2, s. 239; Cristescu, 1995; Kramer, 2017). Sagen drejer sig om, at Stalin i 1951 - dvs. efter Koreakrigens udbrud, som USA valgte at gå ind $\mathrm{i}$ - indkaldte de kommunistiske ledere og forsvarsministrene fra Øst- og Centraleuropa til et strengt hemmeligholdt flerdagesmøde i Moskva i januar for at få dem til inden for kun 2-3 år at opbygge moderne slagkraftige hære $i$ et samlet styrkeopbud på 3 millioner mand, hvoraf over 1,2 millioner skulle stå klar i fredstid. Subov kæder initiativet sammen med den senere sovjetiske generalstabschef Akhromejevs udtalelse om, at krigsdoktrinen dengang gik ud på at opbygge en gigantisk sovjetisk pansernæve med henblik på en modoffensiv, der kunne nå Atlanterhavet ved at slå USA og dets allierede (sammesteds). Ifølge Mark Kramer (2017, s. 37) overtalte Stalin sine nye allierede med, at "USA vil være låst fast i Asien de næste 2-3 år". Ergo havde Stalin antagelig mere end et hævntogt mod Tito - der i 1948 brød med Stalin - i tankerne. CIA og NATO fandt i 1951-1952 udviklingen i og omkring Jugoslavien stærkt foruroligende. Oprettelsen af det økonomiske forum COMECON sætter Kramer (2017) og Subov ind i samme højspændte sikkerhedspolitiske sammenhæng, idet det skete på et ligeledes hemmeligt topmøde i januar 1949 mellem Stalin og hans statholdere. Samtidig tog Sovjetunionens oprustning og krigsmobilisering et lige så gigantisk opsving. I 1948 rådede Stalin over en hær på 2,9 millioner mand mod 5,6 millioner i marts 1953, da han døde (sammesteds). Hvad det egentlig var, Stalin pønsede på, mens Koreakrigen afledte USA, forbliver en af de hemmeligheder, han tog med sig i graven.

Som jeg tidligere skrev, anser Subov hele perioden 1917-1954 for et nationalt traume. Følgelig rummer bind 2 opgørelser over sovjetmagtens samlede forbrydelser 
mod menneskeheden, som enten var eller tangerede folkedrab - begreber, som værket ikke benytter stringent. Således bringes en oversigt over de 53 (!) forskellige folkedeportationer, det kom til, begyndende med fordrivelsen af to kosaksamfund i 1920 og 1921 frem til 1952, hvor man dels fordrev "kulakker« fra det vestlige Hviderusland, dels visse religiøse sekter såsom adventisterne (bind 2, s. 128-129). Tvangskollektiviseringen indebar både folkedrab og et klimaks i fordrivelse med over 2 millioner fordrevne. Yderligere 2,72 millioner blev fordrevet i verdenskrigsårene 1939-1945 - Volga-tyskere, Krimtatarer og tjetjenere m.fl. Budskabet til læseren er, at deportationerne begyndte i Lenins tid med hans fulde accept og var en tilbagevendende sovjetisk praksis, helt indtil Stalin døde. Subov anslår, at sammenlagt 6 millioner mennesker blev ofre for deportationerne (sammesteds).

Hertil kommer, at Subov genopfrisker og supplerer tidligere bragte tal for tab af menneskeliv, hvorom det vedrørende tvangskollektiviseringen bemærkes, at ingen opgjorde hvor mange børn, der omkom (bind 1, 885). Kildematerialet omfatter kun voksne og udgøres af officielle tal for henrettelserne samt dødstallene fra lejrene. Derfor gør Subov klogt i med fed skrift at fremhæve, at nedenstående beregning kun udgør et "et pålideligt minimum " (bind 2, s. 186):

\begin{tabular}{ll}
\hline 1918-1922: „Krigskommunismens«, sultens og Borgerkrigens ofre & 12 millioner \\
1930-1933: Kollektiviseringens, afkulakiseringens og Holodomors ofre & 9 millioner \\
1934-1940: Ofre for deres følger; terror, lejre, Den Sovjetisk-Finske krig & 2,7 millioner \\
1941-1945: Ofre for Den Sovjetisk-Nazistiske Krig & 27 millioner \\
1946-1956: Ofre for sulten i 1947, nedkæmpelse af opstande, lejre & 1,3 millioner \\
\hline 1918-1956: Samlet tab i menneskeliv & 52 millioner \\
\hline
\end{tabular}

Det forfærdelige slutfacit på 52 millioner omkomne stemmer ganske vist ikke overens med det endnu højere tal på 55 millioner dræbte, som konfliktforskeren Rudolph J. Rummel (1990) når frem til for perioden 1917-1953. Det siger blot noget om, at Subovs og hans kollegers tabstal næppe er misvisende som fingerpeg om sovjetmagtens vold mod dens egne.

\section{3-2008: "Nedbrydningen af den totalitære stat og bevægelsen mod et nyt Rusland"}

Selv om behandlingen af den første halvdel af den 74 år lange sovjetiske del af det 20. århundrede udgør det afgørende bidrag til en russisk Vergangenheitsbewältigung, er denne sidste del af værket spændende læsning endda. Subov betoner, at selv ofre for Stalins terror sørgede over hans død. Ligeledes dvæles der ved Stalin-bødlen Berijas paradoksale rolle efter Stalins død, idet det kom til et forbud mod tortur og en vis amnesti. Kapitlerne om Khrusitjovs tid ved magten fremhæver hans vigtige hemmelige tale på den 20. partikongres i 1956, som rehabiliterede tusinder af ofre 
for Stalins justitsmord. Den gav problemer med at opretholde herredømmet over Øst- og Centraleuropa kulminerende med opstanden i Budapest. Hermed begyndte den nedbrydning af det totalitære vælde, som overskriften har som pointe. Subov kalder Khrusitjovs ophævelse af de strenge pasbestemmelser for kolkhosbønderne for "det andet 1861 " med en hentydning til afskaffelsen af livegenskabet i zarismens tid (bind 2, s. 336f.). Khrusitjov forsøgte at bremse militariseringen af samfundsøkonomien, men slog hårdt ned på opstanden i Novotjerkassk i 1962 og stod bag de fatale mellemdistanceraketter i Cuba. Subov bruger den amerikanske historiker William Taubman (2003), når han skildrer Khrusjtjov som uligevægtig i tiden op til kuppet mod ham i 1964. Trods Khrusitjovs boligbyggeri til erstatning for de forfærdelige kommunalki smuldrede folks tiltro til ham.

Ifølge Subov viste den undertippede efterfølger Bresinev sig ferm til at få såvel bønderne som militæret og partiapparatet over på sin side, for han fremstod anderledes godmodig og sindsligevægtig (bind 2, s. 396). Kemien mellem ham og den tjekkoslovakiske reformator Dubcek var god. Alligevel krævede høgene i Politbureauet og i Tjekkoslovakiets nabolande Pragforåret i 1968 bragt til ophør med våbenmagt. Blandt høgene var Andropov, der i 1967 blev indsat som chef for KGB, hvor han trådte i karakter som en afgørende beslutningstager i takt med, at Bresjnev blev mere og mere affældig. Værket bringer et tilpas ubesmykket og fyldigt portræt af Andropov (sammesteds; bind 2, s. 505-507). Subovs beretning om krigen i Afghanistan er både grundig og spændende. Ifølge den begyndte Bresjnev allerede i den afghanske leder Daouds tid at sætte sig tungt på Afghanistan, ligesom KGB i 1977 begyndte at skole folk som Amin i det forfængelige håb, at de ville være pålidelige nikkedukker (bind 2, s. 448). Analysen peger på, at de sovjetiske beslutningstagere blev ofre for dels økonomisk afpresning fra de indbyrdes stridende afghanske venstrefløjsledere, dels deres egen overreaktion på kup i nabolandene Pakistan og Iran - især deres overreaktion på den styrkede amerikanske flådetilstedeværelse i Den Persiske Golf som svar på truslen fra det nye fanatiske anti-amerikanske præstestyre i Iran (bind 2, s. 450-451).

Følgelig spillede de sovjetiske beslutningstageres selvpåtagne forpligtelse til at forsvare "den socialistiske revolution" i Afghanistan dem et puds, da tingene hen over 1979 spinnede ud af kontrol. De ideologiske vagthunde - netop Andropov samt udenrigsministeren Gromyko, forsvarsministeren Ustinov, den grå eminence Suslov og Komintern-veteranen Ponomarjov - forlangte alle væbnet indgriben, så det var forgæves, at militære topfolk som Ogarkov, Akhromejev og Varennikov frarådede interventionen sidst i 1979. Ifølge Tjernajev, dengang en af spidserne i det sovjetiske kommunistparti, vidnede beslutningen om såvel uansvarlighed som alderdomssvækkelse. I Udenrigsministeriet anså man Afghanistan-krigen for »et meningsløst eventyr", "et vidnesbyrd om Bresjnev-regimets fuldstændige nedbrydning" og omsiggribende "stagnation". Eller som Subov (2009) lægger op til: en milepæl i »den totalitære stats nedbrydning ". Alligevel fremhæver Subov vanen tro nogle indiskutable sovjetiske helteskikkelser i denne håbløse krig (bind 2, s. 454). 
Antagelig er denne del af værket skrevet af den internationalt kendte historiker Vladislav M. Subok, fordi pointen her og i Suboks egen monografi er den samme: Afghanistan-krigen var et klimaks i det fatale ideologiske overmod, der besjælede Kreml i 1970'erne (Zubok, 2009, s. 249-254, 259-264). Det gav sig udslag i fremstød i Afrika oven i de økonomisk belastende bastioner Cuba, Vietnam samt Øst- og Centraleuropa. Ifølge Subov/Subok kostede alene Cuba Sovjetunionen 5 milliarder \$ årligt, og de nye afrikanske partnere var alle et dyrt bekendtskab. Det samme var de udsendte sovjetborgere, der for at opretholde deres privilegier så støttekrævende "socialisme« overalt (bind 2, s. 444-445). Dette ligner den strukturøkonomiske argumentation om årsagen til Sovjetunionens fald, som man finder hos RANDøkonomen Valerie Bunce (1985) og stormagtshistorikeren Paul Kennedy (1987). Kennedy-begrebet imperial overstretch bruges ikke, men det fremgår, at Sovjetunionen også rustede sig selv i knæ grundet ambitionen om våbenstrategisk at følge med USA. Subov opsummerer det ideologiske imperiebyggeri, som Sovjetunionen begav sig ud i efter sejren i 1945, med en tabel over "det verdenssocialistiske system", som permanent eller midlertidigt omkalfatrede 30 lande, herunder Kina - dvs. 34 pct. af klodens befolkning (bind 2, s. 504).

Hele samfundet led under Kremls selvbedrag, dog pågik samtidig en humanisering af det sovjetiske system under Khrusjtjov og videre frem (bind 2, s. 334-338, 417 ff.). Franske actionfilm med Jean-Paul Belmondo dukkede op, og folk faldt i svime over de biler og barer, han boltrede sig i, ligesom en vis turisme gjorde det klart, at der ikke var nød og varemangel i Vesten. Med rette krediteres Gorbatjov for at påbegynde genopbygningen af retsstaten (bind 2, s. 527), og Subov undgår den letkøbte kritik af hans fejlslagne reformer, idet sarkasmen reserveres til bagmændene bag augustkuppet i 1991. Jeltsin fremstår opportunistisk, om end sympatien er på hans side, når det gælder de væbnede sammenstød ved det russiske parlament i oktober 1993. Analysen af forløbet omkring den famøse chokterapi og de nødvendige privatiseringer af virksomheder er ikke på niveau med Kotkin (2001), men den tilstræber saglighed og højner oplysningsniveauet om denne omstridte fase af landets historie.

Man skal frem til Putins tid ved magten, før fremstillingen bliver tam og blot gør status for de forskellige postsovjetiske stater. Forinden foretages dog en velgørende tilbageskuende analyse af økonomi og levevilkår samt samfundets moralske habitus i den sensovjetiske og postsovjetiske tid (bind 2, s. 684-720). I Rusland er historikere ofte snævert specialiserede, alene derfor bør man ligesom Pipes (2009) og Torbakov (2011, s. 231, fodnote 83) byde dette livtag med det allermest traumatiske århundrede i landets historie velkommen. Værket er tiltænkt den historieinteresserede læser og ønsker tydeligvis at fremme viden og eftertanke. Men forfatterne fastholder fortælleglæden og krydrer beretningen med smædevers om fx Lenins begravelse, mordet på Kirov og vitser fra Bresjnev-tiden. Resultatet kan stilistisk minde om den ligeledes fortælleglade tyske historiker Karl Schlögel (2017). 


\section{Hvordan blev Subov (2009) modtaget? Om værkets problematiske sider}

Alligevel fik dette værk i genren Vergangenheitsbewältigung en hård medfart. Bind 1 affejes af den russiske historiker Aleksandr Sjisjkov (2010) som "historieforfalskning i stor skala" grundet dets "dumheder og fejlskøn". Sjisjkov anholder den "militant antibolsjevikkiske" slagside og beklikker Subov for at skrive ud fra "en overlevende godsejers position«. Han latterliggør empatien med ikke-russiske folkeslag. Men man får indtryk af, at den egentlige anstødssten for ham og for andre, der dømmer "falsifikation" (Vnimanie - falsifikatsija, 2010) er empatien over for Vlasov i bind $2 .{ }^{6}$ Subov kobles ligefrem sammen med det russiske emigrantmiljøs »kollaboration med fascismen" og med CIA (sammesteds). Hertil kommer et helt andet problem, som antydes af Subovs kritiske medforfatter S. V. Volkov (Wikipedia, 2020), der alligevel anser Subov (2009) for banebrydende.

Fremstillingens liberale Vergangenheitsbewältigung skæmmes nemlig af, at den russiske højrefløjsfilosof Ivan Iljin (1883-1954) ofte gøres til moralsk overdommer - selv om forhold efter hans død (bind 2, s. 398). Portrættet af Iljin (bind 1, s. 825-826) sluger hans fascistoide tænkning råt, og epilogen citerer ærbødigt hans Rusland-mysticisme, og den ellers forfriskende sociologiske tese om manglende solidaritet hægtes på den slavofile Vladimir Solovjov. Venerationen for Iljin - der overfladisk set deles af Putin (Laruelle, 2018) - kunne ses som en fiffig måde at parere kritik på ovenfra, men uanset motivet spøger obskurantismen. Den tjekkiske historiker Daniela Kolenovská (2017) er inde på det samme, når hun afskriver værket som historiefilosofi med rødder i Solsjenitsyn snarere end professionel historie.

Endvidere spænder Subov og hans medforfattere ben for målsætningen om at skrive for den alment interesserede læser ved at indflette en detaljeret kirkehistorie for det ortodokse trossamfund samt andre konfessioner i Rusland. Allerede Solsjenitsyn (2008) mente, at værket voksede ud over alle bredder, og man savner håndfast redigering og præcision. Som ovenfor påpeget rammer Subov plet mange steder for så bagefter at ramme skævt fx om afhopperen Kravtjenko, der blandes sammen med Guzenko. Det bringer mig frem til den sønderlemmende kritik fra den svenske rustningsøkonomiske Rusland-historiker Lennart Samuelson (2010). Hans udgangspunkt er, at sådanne synteser skal være skarpsindige, dvs. skrives med akribi, følgelig anerkender han Sjisjkovs kritik og håner Subovs naivitet. Så er der problemet med uigennemskuelighed, hvad angår forfattere og kilder, selv om man ikke kan forvente et videnskabeligt noteapparat i et formidlende værk som dette. Tit undres man over,

\footnotetext{
${ }^{6}$ Analysen af Medvedevs udvalg til imødegåelse af historieforfalskning hos den norske historiker Pål Kolstø (2019) viser, at der er gået inflation i ordet falsifikation i den russiske historiedebat. Mere herom senere.
} 
hvorfra dette eller hint stammer, selv om hvert kapitel giver relevante tip såsom klassikeren John Erickson (1999).

Konkret slår Samuelson ned på fortolkningen af Molotov-Ribbentrop-pagten, som han finder helt uholdbar. Det skyldes, at Subov kæder pagtens funktion som udløser af Anden Verdenskrig sammen med noget, der antagelig er et falsum, nemlig Stalins krigeriske hemmelige tale til Politbureauet 19. august 1939, som citeres (bind 2, s. 9). Problemet ligger i den manglende kildekritik angående talens autenticitet (herom se Sljutj, 2004). Samuelson (2010) finder det sandsynliggiort, at "talens" ordlyd blev fabrikeret af den daværende franske militære efterretningstjeneste, idet "originalen" i det russiske trofæ-arkiv RGVA i Moskva er en maskinskrevet tekst på fransk. Stalin selv ville næppe bruge ordet partidiktatur, men ville som overbevist leninist kalde tilstanden for partiets hegemoni, vil jeg tilføje.

Samuelson er pikeret over, at Subov bruger ordet golodomor om hungersnøden under Lenin i 1921. I det ordvalg ligger, at det var en politisk påført sult af typen folkedrab analogt med, at man i Ukraine taler om Holodomor vedrørende årene 1932-1933. Subov levner ingen tvivl om, at den senere ukrainske katastrofe og tvangskollektivisering var en forbrydelse i en klasse for sig. Golodomor-terminologien handler blot om at udstille fællestræk i Lenins og Stalins fremfærd over for bønderne som politisk baggrund for hungersnøden, hvad der er belæg for. Her vil jeg citere det danske øjenvidne Hermod Lannung (1978, s. 127), der var aktiv i Nansens humanitære arbejde i Rusland: "Der var i 1922, ja allerede i 1921 på grund af tørke og misvækst hungersnød i dele af Sydrusland, især i Ukraine, samt ved Volga. En medvirkende årsag til, at det var blevet så alvorligt, var ikke blot den forudgående borgerkrig, men en uheldig tvangsafleveringsordning (...)". Det politiske formål bag Lenin-tidens hungersnød dokumenteres tillige af Werth (2003, s. 129-153): at knægte bønderne og siden kirken gennem tvangsinddrivelse af korn vel vidende, at det ville skabe en sult, der ville afkræfte bønderne og hindre dem $i$ at komme kirken og præsterne til hjælp.

Selv om de hårde udfald mod Subov vejer tungest hos Samuelson (2010), bifalder han Subovs pragmatiske, ikke-etniske tilgang til nøglekategorierne russerne/det russiske folk. Den ville nok falde ikke-russiske nationalister for brystet som et tyveri af Ukraines historie fra ukrainerne osv. - altså som identifikation med Sovjetunionen og Det Russiske Imperium. Men netop fordi værket præges af empati over for ikke-russiske folkeslag og for det meste prædiker liberale værdier som frihed, retsstat og individets integritet, gør værket ikke just knæfald for den aggressive russiske nationalisme endsige den sovjetiske imperialisme. Samuelson kommenterer ikke på Subovs stof om den kolde krig, men godtager det som "velkendt" fra andre værker. Den amerikanske historiker Walter Laqueur (2011) har imidlertid lavet en sammenlignende anmeldelse af Subov (2009) og koldkrigshistorien hos Leffler og Westad (2010), der falder ud til fordel for det russiske værk. Laqueur roser det for at tage KGBs sandsynlige orkestrering af paveattentatet i 1981 op (bind 2, s. 472), ligesom det lægger anderledes vægt på at udstille offensive sider af den sovjetiske fremfærd. 


\section{Konklusion: Er Subov m. fl.s historieskrivning en enlig svale?}

Der er andre enkeltheder i dette mammutværk om Ruslands samtidshistorie, man kunne slå ned på. Men min kronologiske gennemgang af styrkerne i Subov-holdets passionerede historieskrivning efterfulgt af eksempler på den heftige kritik heraf skulle give læseren føling med indholdet. Værkgennemgangen viser, at Subov (2009) er i samklang med megen lødig vestlig og russisk forskning, så jeg oplever værkets påfaldende "personlighedsspaltning « mellem oplysning med sigte på liberal Vergangenheitsbewältigung og slavofil obskurantisme i dets veneration for Iljin som den største svaghed. For manglen på kildegennemskuelighed og skarpsindighed/akribi samt den slappe redigering opvejes næsten af forfatterholdets civilcourage angående det sensitive stof om 1941-1945, der jo er kilden til Putin-æraens Stalinromantik. Historieskrivningen om den sensovjetiske epoke er medrivende, og hvad angår den omstridte tidlige sovjetiske fase, rammer Subov ikke for alvor skævt trods kritikken mod ham. Dog udmøntes nøgletesen om agens som historiens drivkraft mest i henholdsvis Lenins, Stalins og den sensovjetiske elites topstyring af samfundet. Den folkelige understrøm af angiveri, hævntørst og anden meddelagtighed i volden mod samfundet bliver blot en medvirkende faktor, lige så den civilcourage, der hyldes. Men overordnet lykkes værket som en spændende syntese om Ruslands 20. århundrede.

Nok så vigtigt kan værkets førsteudgave fra 2009 som sagt ses som led i den da Kreml-sanktionerede Vergangenheitsbewältigung af Ruslands sovjetiske fortid. Som understreget afTorbakov (2011, s. 223 og 231, fodnote 83) kom den officielle anerkendelse af Subov (2009) til udtryk ved, at den udenrigs- og sikkerhedspolitiske høg Sergej Karaganov udgav en ovenud begejstret omtale i regeringsavisen Rossijskaja Gazeta. Han brugte ordet "fantastisk", især fordi de russiske emigranters historie indgår, og var kun betænkelig ved empatien forVlasov (Karaganov, 2010). Som højtstående medlem af Præsidentrådet for udvikling af civilsamfundet og menneskerettighederne indtog Karaganov her rollen som liberal på de indre historiepolitiske linjer (Sherlock, 2016). Som omtalt af Enstad (2011, s. 339) fulgte Karaganov Subov-rosen op ved over for den daværende præsident Medvedev på en officiel historiepolitisk konference i februar 2011 at forlange et opgør med Ruslands "selvpåførte folkedrab« (samogenotsid). Forud for det trådte Kremls rådgiver for menneskerettigheder Mikhail Fedotov ligeledes i karakter vedrørende Vergangenheitsbewältigung (Grove, 2010).

Forblev Subov (2009) så en enlig svale? Både nej og ja! For på den ene side omtaler Sherlock (2016, s. 7) to historiebøger fra 2015 og 2016, der fraviger Filippovsystemets Stalin- og statsvenlige historieskrivning, om end de ligesom Subov (2009) behandler Putin-epoken med fløjshandsker. Endnu mere bemærkelsesværdig er den stadige genudgivelse af et etbindsværk om Ruslands samlede historie "fra Rjurik til Putin" skrevet af Sankt Petersborg-historikeren Jevgenij Anisimov (2014). ${ }^{7}$ Han

\footnotetext{
${ }^{7}$ Jeg takker Torben Heuer for at have lånt mig Anisimov (2014) samt flere andre russiske samtidshistorier.
} 
skriver et dejligt ligefremt russisk og bruger kategorier, som den menige læser nemt fænges af: folk, begivenheder og datoer (liudi/sobytija/daty). Den går mere Putin- og magtkritisk til værks end andre historiebøger, jeg kender, og når således reelt videre end Subov (2009), selv om Anisimov (2014) modsat Subov-værket desværre er kemisk renset for kildehenvisninger. Langt hovedparten af Anisimovs læsere bifalder hans historieskrivning ifølge russiske netboghandel-hjemmesider, så måske han har den folkelige gennemslagskraft, som Subov-holdet nok savner? I så fald ikk' så ringe!

På den anden side ser selve den Kreml-sanktionerede pluralisme til fordel for oprigtig Vergangenheitsbewältigung ud til at være forbi, som allerede antydet af Sherlock (2016). Mere præcist formuleret er det historieskrivningen om Ruslands selverklærede identitets- og sikkerhedspolitisk formative år 1941-45 under Anden Verdenskrig, der nu er blevet "sikkerhedgjort", dvs. underlagt tabu (Bækken og Enstad, 2020). Opgøret med pluralismen fremgår af den opfølgende ændring af Ruslands forfatning af 1993, idet den nye $\$ 67$ gør Den Russiske Føderation, altså staten, til "garant for den historiske sandhed om forsvaret af Fædrelandet" og forbyder ringeagt over for befolkningens heltegerninger i denne sammenhæng (Veser, 2020). Sammenhængen med Putins personlige monistiske og assertive historiesyn er klar, og Kolstø (2019, s. 757) kæder ovenikøbet hans historiesyn sammen med fyringen af Subov i 2014 - efter at Kreml-insideren Karaganov offentliggjorde sin hyldest af selvsamme Subovs værk. Så selv om kampagnen mod historieforfalskning rent terminologisk er lagt på hylden, bliver svaret på spørgsmålet, om Subov (2009) står alene, mere og mere et ja. Værket er ret enestående og næsten lige så omstridt som Filippov-systemet. Men der ligger selvfølgelig et håb om bedre tider for Ruslands påkrævede Vergangenheitsbewältigung i det, når Sherlock (2016) bedømmer Kremls historiepolitik som alt andet end urokkelig, snarere opportunistisk og instrumentaliseret (Sherlock, 2016).

\section{Om artiklen}

Stor tak til Aleksanteri-instituttet i Helsinki for en måneds husly i 2020 - især til Katri Pynnöniemi, Margarita Savadskaja, Jeremy Smith og Eeva Korteniemi. Og tak til Peter Bugge, Aarhus Universitets afdeling for Centraleuropastudier, for hjælp med det tjekkiske.

\section{Referencer}

Albats, E. \& Tsukanova, L. (2013). Jedinyj utjebnik dlja razorvannogo obsjtjestva. New Times, No. 39,25 nov. (14 s.). Hentet 16. August 2020 fra https://newtimes.ru/articles/detail/74548

Anisimov, E. V. (2014/2019). Istorija Rossii ot Rjurika do Putina. Ljudi. Sobytija. Daty. Moskva m.v.: Piter.

Bonwetsch, B. (2000). War as a 'breathing space': Soviet intellectuals and the great patriotic war. I R. W. Thurston \& B. Bonwetsch (Red.), The people's war. Responses to World War II in the Soviet Union (s. 137-153). Urbana and Chicago: University of Illinois Press. 
Brandenberger, D. (2009). A new short course? A. V. Filippov and the Russian state's search for a 'usable past'. Kritika, (10)4, 825-833.

Bunce, V. (1985). The empire strikes back: The transformation of the Eastern bloc from a Soviet asset to a Soviet liability. International Organization, 39(1) Winter, 1-46.

Bækken, H. \& Enstad, J. D. (2020). Identity under siege: Selective securitization of history in Putin's Russia. The Slavonic and East European Review, 98(2), 321-344.

Cristescu, C. (1995). Strict Secret de importanta deosebita - Ianuarie 1951: Stalin decide inarmarea Romaniei ("Af yderst hemmelig betydning - januar 1951: Stalin beslutter at opruste Rumænien"). Magazin Istoric, (29) 10, 15-23.

Danilov, A. A. (2008). Istorija Rossii 1900-1945. Kniga dlja utjitjelja. 11 klass. Moskva: Prosvesjtsjenije.

Danilov, A. A. \& Filippov, A. V. (Red.) (2012). Istorija Rossii. 1900-1945. 11 klass: utjebnik dlja obsjtjeobrasovatelnykh utjresjdenij. Moskva: Prosvesjtjenije.

Danilov, A. A., Utkin, A. I. \& Filippov, A. V. (Red.) (2007). Istorija Rossii. 1945-2007. Moskva: Prosvesjtjenije.

Deutsche Welle (24. December, 2019). Putin fires fresh salvo on Molotov-Ribbentrop pact, this time singling out Poland. Hentet 29. april 2020 fra https://www.dw.com/en/putin-fires-fresh-salvo-on-molotov-ribbentroppact-this-time-singling-out-poland/a-51788971

Enstad, J. D. (2011). Putinistisk historiepolitikk: Oppussing af fortiden i Putins Russland. Nordisk Østforum, 25(4), 321-344.

Erickson, J. (1999). The road to Stalingrad. New Haven:Yale University Press.

Filippov, A. V. (2007). Novejsjasja istorija Rossii. 1945-2006. Kniga dlja utjitjelja. Moskva: Prosvesjtsjenije.

Friedrich, C. J. \& Brzezinski, Z. K. (1956). Totalitarian dictatorship and autocracy. Cambridge MA: Harvard University Press.

Grove, T. (2010, 6. Desember). Russia must exorcise Stalin's legacy - Kremlin aide. Reuters.

Heikka, H. (2000). Beyond the cult of the offensive. The evolution of Soviet/Russian strategic culture and its implications for the Nordic-Baltic region. Helsinki: Ulkopoliittinen Instituutti \& Institut für Europäische Politik.

Jacobsen, K. (2012). Lenin. Biografi. København: Informations Forlag.

Jowitt, K. (1992). New world disorder. The Leninist extinction. Berkeley: University of California Press.

Karaganov, S. (2010). Drugaja nasja istorija. Rossijskaja Gaseta, 19. marts. Hentet 29. april 2020 fra http:// svop.ru/news/2637/

Kenez, P. (2006). A history of the Soviet Union from the beginning to the end. Second edition. Cambridge/NewYork: Cambridge University Press.

Kennedy, P. (1987). The rise and fall of the great powers. Economic change and military conflict from 1500 to 2000. New York: Random House.

Kolenovská, D. (2017). Dejiny Ruska bez hranic. Ustav pro soudobe dejiny AV CR. Issue No. 1-2, ss. 228-236.

Kolesnikov, A. (2019). Bolsjoj khorosjij Stalin, malenkij plokhoj Stalin, Vedomosti.ru 26. marts. Hentet 29. april 2020 fra https://www.vedomosti.ru/opinion/columns/2019/03/27/797472-stalin

Kolstø P. (2019). Dmitrii Medvedev's commission against the falsification of history: Why was it created and what did it achieve? A reassessment. The Slavonic and East European Review, 97(4), 738-760.

Kotkin, S. (2001). Armageddon averted. The Soviet collapse, 1970-2000. Oxford \& New York: Oxford University Press.

Kotkin, S. (2014). Stalin. Volume I: Paradoxes of power, 1878-1928. New York: Penguin Press.

Kotkin, S. (2017). Stalin. Volume II: Waiting for Hitler, 1928-1941. New York \& UK: Penguin Random House \& Allen Lane.

Kramer, M. (2017). Stalin, the split with Yugoslavia, and Soviet-East European efforts to reassert control, 1948-53. I S. Rajak, K. E. Karamouzi \& E. Hatzivassiliou (Red.), The Balkans in the ColdWar (s. 29-63). London: Palgrave Macmillan.

Krammer, A. (1971). Russian counterfeit dollars: A case of early Soviet espionage. Slavic Review, 30(4), 762-773.

Kratkij kurs (1938). Istorija Vsesojuznoj Kommunistitjeskoj Partii (bol'sjevikov). Stalin, J. V. (Red.). OGIZ Gosizdat.

Kulavig, E. (2010). Den Russiske Revolution 1917 - et folks tragiske kamp for frihed. København: Gyldendal.

Langen, U. (2020). Min og hans mailkorrespondence 14., 15. og 26. juli.

Lannung, H. (1978). Min russiske ungdom. 1917-1919 og 1922-24. København: Gyldendal.

Laqueur, W. (2011). The Cold War: Two histories, two narratives. I Harvest of a decade: Disraelia and other eEssays. (s. 103-108). Piscataway, NJ: Transaction Publishers. 
Laruelle, M. (2018). Is Putin's Russia really 'fascist'? A comment on Timothy Snyder. PONARS Policy Memo 539, September (7 ss.).

Leffler, M. P. \& Westad, O. A. (Red.) (2010). The Cambridge history of the Cold War. Volume I-III. Cambridge: Cambridge University Press.

Linz, J. J. (2000). Totalitarian and authoritarian regimes. Boulder \& London: Lynne Rienner.

Litvin, A. \& Keep, J. (2005). Stalinism. Russian and western views at the turn of the millennium. London \& New York: Routledge.

Miller, A. (2010). Russia: Power \& history. I S. A. Greene (Red.), Engaging history. The problems and politics of memory in Russian and the post-socialist space, working papers 2 (s. 13-25). Carnegie Moscow Center.

Miller, A. (2020). Russia and Europe in memory wars. NUPIWorking Paper 887 (20 s.).

Musial, B. (2008). Kampfplatz Deutschland. Stalins Kriegspläne gegen den Westen. Berlin: Propyläen.

Naimark, N. (2010). Stalin's genocides. Princeton \& Oxford: Princeton University Press.

Pipes, R. (2009, 5. desember). A new Russian history that's sensational for the right reasons. Radio Free Europe/ Radio Liberty.

Poulsen, N. B. (2008). Den Store Fedrelandskrig. Statsmagt og mennesker $i$ Sovjetunionen 1939-55. København: Høst \& Søn.

Poulsen, N. B. (2020, 27. juni). Som historiestuderende ville Vladimir Putin være meget tæt på at dumpe. Information/Moderne Tider.

Putin, V. V. (2020). Vladimir Putin: The real lessons of the $75^{\text {th }}$ anniversary of World War II. The National Interest, June 18 (12 s.).

Riisbro, J. B. (2015). Georg Laursen. Fra malersvend til sovjetagent. Første del. I Arbejderhistorie nr. 1, ss. 6-36.

Riisbro, J. B. (2016). Georg Laursen. Fra malersvend til sovjetagent. Anden del. I Arbejderhistorie nr. 1, ss. 64-102.

Rummel, R. J. (1990). Lethal politics. Soviet genocides and mass murders, 1917-1987. Piscataway, NJ: Transaction Publishers.

Samuelson, L. (2000). Plans for Stalin's war machine. Tukhachersky and military economic planning 1925-1941. Basingstoke: Macmillan.

Samuelson, L. (2010). Reflections on the historiography of a reactionary era (s. 1-13) \& Samuelson comments on Zubov's comment: Further reflections on the historiography of a reactionary epoch. Introductory remarks concerning the 2009-2010 launch of new history textbook (s. 33-43). Baltic Worlds, Nr. 2. Hentet 29. April 2020 fra http://balticworlds.com/reflections-on-the-historiography-of-a-reactionary-era Schlögel, K. (2017). Das sowjetische fahrhundert. Archäologie einer untergegangenen Welt. München: C. H. Beck.

Service, R. (2005). Stalin. A biography. Cambridge, MA: Harvard University Press.

Sherlock, T. (2011). Confronting the Stalinist past: The politics of memory in Russia. The Washington Quarterly, 34(2), 93-109.

Sherlock, T. (2016). Russian politics and the Soviet past: Reassessing Stalin and Stalinism under Vladimir Putin. Communist and Post-Communist Studies, 30, 1-15.

Sjisjkov, A. (2010). Golovokrusjenie bes uspekhov. Istorija Rossii netraditsionnoj orientatsii ot professora Subova. Rodina, 6, 2-5.

Skak, M. (2009). Mod en Vergangenheitsbewältigung i Rusland? Udenrigs, 64(1), 56-64.

Slutj, S. Z. (2004). Retj Stalina, kotoroj ne bylo. Otetjestvennaja Istorija, 1, 113-139.

Solsjenitsyn, A. (2008). O Solsjenitsyne i knige "Istorija Rossii. XX vek«, bloggen Livejournal/russia_xx. Hentet 30. april $2020 \mathrm{fra}$ https://russia-xx.livejournal.com/6074.html

Stites, R. (2000). Soviet Russian wartime culture: Freedom and control, spontaneity and consciousness. I R. W. Thurston \& B. Bonwetsch (Red.), The people's war. Responses to World War II in the Soviet Union (s. 171-184). Urbana and Chicago: University of Illinois Press.

Stone, D. R. (2000). Hammer and rifle. The militarization of the Soviet Union, 1926-1933. Lawrence, Kansas: University of Kansas Press.

Subov, A. B. (Red.) (2009). Istorija Rossii. XX vek. Tom I: 1894-1939, Tom II: 1939-2007. Moskva: Astrel.

Subov, A. B. (2010). Andrej Subov o termine "sovetsko-natsistskaja vojna", bloggen livejournal/russia_xx. Hentet 30. april 2020 fra https://russia-xx.livejournal.com/92043.html

Subov, A. B. (Red.) (2017). Istorija Rossii. XX vek. Tom I: Kak Rossija sjla k XX veku. Ot natjala tzarstvovanija Nikolaja II do kontsa Grazjdanskoj Vojny (1894-1922). Tom II: Epokha Stalinisma (1923-1953). Tom III: Degradatsija totalitarnogo gosudarstva $i$ dvisjenie $k$ novoj Rossii (1953-2008). Moskva: Eksmo.

Syrov, S. N. (1979). Stranitsy istorii. Kniga dlja tjenija na russkom jasyke. Vtoroe isdanije. Moskva: Russkij Jasyk. Taubman, W. (2003). Khrushchev. The man and his era. New York \& London: W. W. Norton. 
Thies, J. (2012). Hitler's plans for global domination: Nazi architecture and ultimate war aims. New York: Berghahn Books.

Torbakov, I. (2011). History, memory and national identity. Understanding the politics of history and memory wars in post-Soviet lands. Demokratizatsiya. The fournal of Post-Soviet Democratization, 19(3), 209-232.

Veser, R. (2020). Hitler, der böse Westen und die gute Sowjetunion, Frankfurter Allgemeine Zeitung, 1. juli.

Vnimanie - falsifikatsija (2010, 30. april). Stenogramma zasedanija kluba "Konferentsija Realnaja Vojna". Tsentr Kurginjana. Hentet 30. juli 2020 fra http://www.kurginyan.ru/clubs.shtml?cat=60\&id=484

Werth, N. (2003). En stat mod sit folk. I S. Courtois et al. (Red.), Kommunismens sorte bog. Forbrydelser, terror, undertrykkelse (s. 49-299). København: Høst \& Søn.

Wikipedia (2020). Istorija Rossii. XX vek. Hentet 29. april 2020 fra https://ru.wikipedia.org/wiki/История_ России._XX_век

Zubok, V. M. (2009). A failed empire. The Soviet Union in the Cold War from Stalin to Gorbachev. With a new preface by the author. Chapel Hill: The University of North Carolina Press.

Yaffa, J. (2014). Putin's new war on 'traitors. The New Yorker, 28. mars (4. s.). 